\title{
Research Article \\ Effects of the Domestic Cooking on Elemental Chemical Composition of Beans Species (Phaseolus vulgaris L.)
}

\author{
Alessandra S. T. Ferreira, ${ }^{1}$ Juliana Naozuka, ${ }^{1}$ Gislayne A. R. Kelmer, ${ }^{2}$ and Pedro V. Oliveira ${ }^{2}$ \\ ${ }^{1}$ Universidade Federal de São Paulo, 275 Prof. Artur Riedel Street, 09972270 Diadema, SP, Brazil \\ ${ }^{2}$ Instituto de Química, Universidade de São Paulo, 748 Prof. Lineu Prestes Avenue, 05513-970 São Paulo, SP, Brazil \\ Correspondence should be addressed to Juliana Naozuka; jnaozuka@gmail.com
}

Received 18 November 2013; Accepted 28 January 2014; Published 2 March 2014

Academic Editor: Vassiliki Oreopoulou

Copyright ( 2014 Alessandra S. T. Ferreira et al. This is an open access article distributed under the Creative Commons Attribution License, which permits unrestricted use, distribution, and reproduction in any medium, provided the original work is properly cited.

Cooking is imperative for beans owing to the presence of compounds that can negatively affect nutritional value. Additionally, the heating of beans can increase protein digestibility and induce desirable sensory properties. However, cooking also causes considerable changes in the composition of numerous chemical constituents, including amino acids, vitamins, and minerals. For this, effects of domestic cooking on the essential element concentrations in various beans species (Phaseolus vulgaris L.) were investigated using jalo, fradinho, rajado, rosinha, bolinha, black, and common species. Elemental determination was made with flame atomic absorption spectrometry and inductively coupled plasma optical emission spectrometry after sample digestion in a closed-vessel microwave oven using a diluted oxidant mixture. Analytical methods were evaluated with an addition and recovery test and analysis of certified reference materials (apple and citrus leaves). $\mathrm{Ca}, \mathrm{Cu}, \mathrm{K}$, and $\mathrm{Mg}$ were present mainly in rajado, $\mathrm{Cu}$ in jalo, $\mathrm{Fe}$ in black, $\mathrm{S}$ and $\mathrm{Zn}$ in fradinho, and $\mathrm{P}$ in rosinha species. Thermal treatment did not affect $\mathrm{Cu}, \mathrm{Fe}, \mathrm{S}$, and $\mathrm{Zn}$ concentrations, but it increased $\mathrm{Ca}, \mathrm{K}, \mathrm{Mg}, \mathrm{P}$, and $\mathrm{Zn}$ concentrations in jalo and black species. Ca concentration decreased in fradinho and rajado species, as did $\mathrm{Fe}$ concentration in jalo and rajado species.

\section{Introduction}

Brazil is the largest worldwide producer (2.2-2.5 million tons on approximately 5 million hectares cultivated) and consumer (around $16 \mathrm{~kg}$ per capita) of beans [1-3]. The Brazilian food pyramid shows beans in a group of their own, and the Food Guide for the Brazilian Population recommends the consumption of at least one portion of beans per day [4]. Beans are one of the main protein sources for Brazilians [1-3].

There are several typical Brazilian Phaseolus species, including jalo, rosinha, fradinho, rajado, bolinha, common ("carioca"), and black. In general, these species are good sources of vitamins, minerals ( $\mathrm{K}, \mathrm{Ca}, \mathrm{Mg}, \mathrm{P}$, and Fe salts), protein $(20-25 \%)$, and complex carbohydrates $(50-60 \%)[2,5,6]$. Besides being nutritionally important, beans serve as rich sources of bioactive compounds such as enzyme inhibitors, lectins, phytates, oligosaccharides, and phenolic compounds with potential health implications [7]. Importantly, the elemental chemical composition of beans varies with species, geographic origin (soil, water, pesticides, insecticides, and fertilizers), and climate [8].

Given the nutritional importance of beans, differences in the elemental chemical composition of Phaseolus species should be evaluated in beans cooked for human consumption. Cooking is imperative for beans owing to the presence of compounds such as trypsin inhibitors, lectins, phytates, polyphenols (especially tannins), and oligosaccharides (raffinose and stachyose) that can negatively affect nutritional value. Trypsin inhibitors and lectins are thermolabile, disappearing after proper cooking. Other compounds are thermostable, but their concentrations are reduced by dissolution in water [4].

The heating of beans can increase protein digestibility from $25-60 \%$ (raw) to $85 \%$ (cooked) depending on the species and cooking method [9]. Furthermore, cooking induces desirable sensory properties in beans, such as sweet taste, cooked bean flavour, and soft and mushy textures [2]. However, cooking also causes considerable changes in the 
composition of numerous chemical constituents, including amino acids, vitamins, and minerals [5].

Cooking decreases carbohydrate content and increases the protein content of kidney beans. A significant decrease in the content of all amino acids, especially methionine, tyrosine, and threonine, has also been observed for this species [10]. Studies with other types of beans and legumes have also revealed changing mineral content. Essential elements lost during cooking lixiviate to the cooking water, and bean preparations consumed with their cooking water can retain those minerals $[4,11]$. However, heating can alter elemental chemical species and, consequently, their bioavailability.

The aim of this study was to evaluate the effects of domestic cooking on the essential elements $(\mathrm{Ca}, \mathrm{Cu}, \mathrm{Fe}, \mathrm{K}$, $\mathrm{Mg}, \mathrm{P}, \mathrm{S}$, and $\mathrm{Zn}$ ) compositions of seven Phaseolus species. Elemental determination was carried out with inductively coupled plasma optical emission atomic spectrometry (ICP OES) and flame atomic absorption spectrometry (F AAS) after acid digestion of raw and cooked beans using a diluted oxidant mixture and a closed-vessel microwave oven.

\section{Materials and Methods}

2.1. Reagents and Samples. Seven Phaseolus species (common, black, rajado, rosinha, bolinha, fradinho, and jalo) were purchased at a local market in São Paulo. Two brands were selected with mass of $500 \mathrm{~g}$ of beans. Six species (common, black, jalo, rosinha, rajado, and bolinha) were of the same brand. The geographic origin of the species are São Paulo (rosinha, rajado, and bolinha) and Minas Gerais (common, black, fradinho, and jalo), according to the producers. Apple (SRM 1515) and citrus (SRM 1572) leaves as standard reference materials from the National Institute of Standards and Technology (Gaithersburg, MD) were used to check the accuracy of the analytical methods.

All solutions were prepared from analytical reagent grade chemicals using high-purity deionised water obtained from a Milli-Q water purification system (Millipore, Belford, MA). Analytical grade $65 \%(\mathrm{w} / \mathrm{v}) \mathrm{HNO}_{3}$ distilled in a quartz subboiling still (Marconi, Piracicaba, Brazil) and 30\% (w/v) $\mathrm{H}_{2} \mathrm{O}_{2}$ (Merck, Darmstadt, Germany) were used for sample digestion. Titrisol standard solutions of $1000 \mathrm{mg} / \mathrm{L}$ of all elements (Merck, Darmstadt, Germany) were used to prepare the reference analytical solutions in $0.14 \mathrm{~mol} / \mathrm{L} \mathrm{HNO}_{3}$. Analytical curves were prepared with the following reference solutions: $10-200 \mathrm{mg} / \mathrm{L}$ of $\mathrm{Ca}, \mathrm{K}, \mathrm{Mg}, \mathrm{P}$, and S; $1.5-6.0 \mathrm{mg} / \mathrm{L}$ of $\mathrm{Cu} ; 1.0-3.0 \mathrm{mg} / \mathrm{L}$ of $\mathrm{Fe}$; and $0.20-0.80 \mathrm{mg} / \mathrm{L}$ of $\mathrm{Zn}$. All solutions were prepared in $0.14 \mathrm{~mol} / \mathrm{L} \mathrm{HNO}_{3}$.

2.2. Preliminary Sample Preparation. Raw beans were cleaned with deionized water and dried in an oven (model 515, FANEM, São Paulo, Brazil) at $60^{\circ} \mathrm{C}$ to constant mass. Then, one part of the raw beans was ground using a cryogenic grinder (MA 775 model, Marconi, Brazil), with $5 \mathrm{~min}$ of freezing followed by three cycles of 2 min of grinding, with $1 \mathrm{~min}$ of freezing between each cycle $[12,13]$. The rest of the raw beans were cooked.
TABLE 1: Instrumental parameters for elemental and residual carbon determinations using axially viewed ICP OES.

\begin{tabular}{|c|c|}
\hline Pump rotational speed & $25 \mathrm{rpm}$ \\
\hline Pressure of nebulizer gas & $0.1 \mathrm{MPa}$ \\
\hline Intermediate gas flow & $1.0 \mathrm{~mL} / \mathrm{min}$ \\
\hline Power (W) & $1250 \mathrm{~W}$ \\
\hline Vazão do gás do plasma gas flow & $12 \mathrm{~L} / \mathrm{min}$ \\
\hline \multicolumn{2}{|c|}{ Analytical wavelength $(\mathrm{nm})$ - axial view } \\
\hline Ca 396.8 & Mg 279.5 \\
\hline P 185.9 & S 180.7 \\
\hline
\end{tabular}

2.3. Cooking Procedure. To apply cooking techniques similar to those used in homes $[3,14]$, we soaked raw beans (approximately $20 \mathrm{~g}$ ) in tap water at room temperature for $24 \mathrm{~h}$. The soaking water was discarded, a volume of deionized water (approximately $200 \mathrm{~mL}$ ) was added to the soaked beans, and the beans were cooked on an electric hotplate until they were soft and $90 \%$ of water had evaporated. The total cooking time ranged from 45 (bolinha) to 60 (rosinha) min, depending on the Phaseolus species. Cooked beans and water were mixed and dried in an oven at $60^{\circ} \mathrm{C}$ until constant mass was reached. The mixture was then ground using a cutting mill (GM 200 model, Retsch, Germany) for $3 \mathrm{~min}$ at $1800 \times \mathrm{g}$.

2.4. Sample Digestion. Raw and cooked beans (and certified material of apple leaves) were submitted to acid digestion in a closed-vessel microwave system (Multiwave 3000, Anton Paar, Austria) equipped with 16 fluoropolymer vessels and a ceramic vessel jacket. These components supported a maximum temperature and pressure of $240^{\circ} \mathrm{C}$ and $4 \mathrm{MPa}$, respectively. Sample masses ranging from 150 to $250 \mathrm{mg}$ were digested using a diluted oxidant mixture $\left(2 \mathrm{~mL} \mathrm{HNO}_{3}+1 \mathrm{~mL}\right.$ $\mathrm{H}_{2} \mathrm{O}_{2}+3 \mathrm{~mL} \mathrm{H}_{2} \mathrm{O}$ ) [15]. The heating program was performed in three steps (temperature $/{ }^{\circ} \mathrm{C}$; $\mathrm{ramp} / \mathrm{min}$; hold $/ \mathrm{min}$ ): (1) $(140 ; 5 ; 1) ;(2)(180,4,5)$; and $(3)(220,4,10)$. A fourth step for cooling the system through forced ventilation was carried out for $20 \mathrm{~min}$. After digestion, samples and blank solutions were transferred to plastic flasks and made up to $10 \mathrm{~mL}$ with deionized water. The digestion procedure was carried out in triplicate for each sample.

2.5. $\mathrm{Ca}, \mathrm{K}, \mathrm{Mg}, \mathrm{P}$, and $S$ Determinations. An iCAP 6300 Duo ICP optical emission spectrometer (Thermo Fisher Scientific, Cambridge, England) equipped with axially and radially viewed plasma was used throughout the study. The spectrometer was equipped with a simultaneous charge injection device detector allowing measurements from 166.25 to $847.00 \mathrm{~nm}$. The Echelle polychromator was purged with argon. The introduction system was composed of a cyclonic spray chamber and a Meinhard nebulizer. The injector tube diameter of the torch was $2.0 \mathrm{~mm}$. The instrumental conditions for ICP analysis are given in Table 1.

Limit of detection (LOD) was calculated using the background equivalent concentration (BEC) and signal-tobackground ratio (SBR) according to IUPAC recommendations $[15,16]: \mathrm{BEC}=C_{\mathrm{rs}} / \mathrm{SBR} ; \mathrm{SBR}=\left(I_{\mathrm{rs}}-I_{\text {blank }}\right) / I_{\text {blank }}$; 

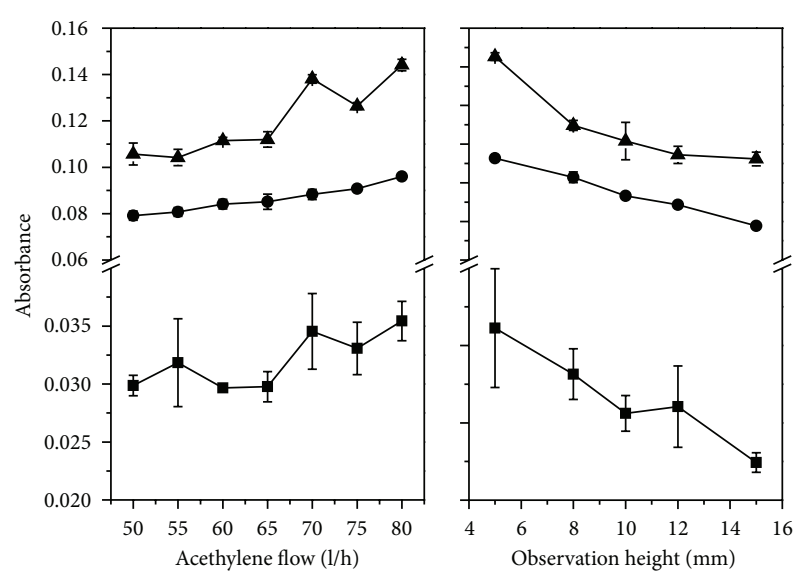

FIGURE 1: Optimization of flame chemical composition (acetylene flow) and observation height using analytical solutions of $1.0 \mathrm{mg} \mathrm{L}^{-1}$ $\mathrm{Cu}(\boldsymbol{\bullet}), 1.0 \mathrm{mg} \mathrm{L}^{-1} \mathrm{Fe}(\bullet)$, and $0.2 \mathrm{mg} \mathrm{L}^{-1} \mathrm{Zn}(\boldsymbol{\Delta})$.

$\mathrm{LOD}=3 \times \mathrm{BEC} \times \mathrm{RSD} / 100$, where $C_{\mathrm{rs}}$ is the concentration of multielemental reference solution $(10 \mathrm{mg} / \mathrm{L}), I_{\mathrm{rs}}$ and $I_{\text {blank }}$ are the emission intensities for the multielemental reference $(10 \mathrm{mg} / \mathrm{L})$ and blank solutions, respectively, and RSD is the relative standard deviation for 10 consecutive measurements of blank solution. The limit of quantification (LOQ) was calculated as $10 \times \mathrm{LOD}$. LOQ was equal to $3 \times \mathrm{LOD}$. The values were given in $\mu \mathrm{g} \mathrm{g}^{-1}$, considering a sample mass of $250 \mathrm{mg}$ and a final volume of $10 \mathrm{~mL}$. Citrus leaves (SRM 1572) were submitted to acid digestion and used to check the accuracy of the analytical method.

2.6. $\mathrm{Cu}, \mathrm{Fe}$, and $\mathrm{Zn}$ Determination. An atomic absorption spectrometer (Model AAS Vario 6, Analytik Jena AG, Jena, Germany) equipped with a hollow cathode lamp of $\mathrm{Cu}$ $(324 \mathrm{~nm}, 4 \mathrm{~mA}$, and slit $0.8 \mathrm{~nm}), \mathrm{Fe}(259 \mathrm{~nm}, 4 \mathrm{~mA}$, and $0.8 \mathrm{~nm})$, and $\mathrm{Zn}(213 \mathrm{~nm}, 4 \mathrm{~mA}$, and $0.5 \mathrm{~nm})$ and a deuterium lamp for background correction were used. For elemental determination with F AAS, acetylene flow was optimized, ranging from 50 to $80 \mathrm{Lh}^{-1}$ in increments of $5 \mathrm{~L} \mathrm{~h}^{-1}$, with constant air flow $\left(430 \mathrm{~L} \mathrm{~h}^{-1}\right)$ and observation height $(6 \mathrm{~mm})$. The observation height was evaluated $(5,8,10,12$, and $15 \mathrm{~mm})$ in the best acetylene flow for each element of interest. Under each condition, absorbance signals were obtained in triplicate using analytical solutions of $1.0,1.0$, and $0.2 \mathrm{mg} \mathrm{L}^{-1}$ of $\mathrm{Cu}, \mathrm{Fe}$, and $\mathrm{Zn}$, respectively.

LOD was calculated using the standard deviation of 10 measurements of analytical blank ( $\mathrm{LOD}=3 \times \sigma_{\text {blank }}$, where $\sigma$ is the standard deviation). LOQ was equal to $3 \times \mathrm{LOD}$. The values were obtained in $\mu \mathrm{g} \mathrm{g}^{-1}$, considering a sample mass of $250 \mathrm{mg}$ and a final volume of $10 \mathrm{~mL}$.

Addition of $1 \mathrm{mg} \mathrm{L}^{-1}$ of $\mathrm{Cu}^{2+}, 1 \mathrm{mg} \mathrm{L}^{-1} \mathrm{Fe}^{3+}$, and $0.5 \mathrm{mg} \mathrm{L}^{-1} \mathrm{Zn}^{2+}$ and recovery tests were used to verify the reliability of the procedure. Additions of analytical solutions of $\mathrm{Cu}, \mathrm{Fe}$, and $\mathrm{Zn}$ in raw and cooked beans were made before acid digestion in the microwave oven. Apple leaves (SRM 1515) were submitted to acid digestion and used to check the accuracy of the analytical method.

\section{Results and Discussion}

3.1. Optimization of Flame Conditions. The appropriated chemical environment of the air-acetylene flame is suitable for breaking down most compounds to atoms with reasonable efficiency. The flame conditions can alter the atomic precursors or form refractory species of the element of interest, or both [17]. As shown in Figure 1, the variation of fuel flow had no effect on the atomization of $\mathrm{Cu}$ and Fe. However, $\mathrm{Zn}$ showed significant increase in absorbance signal from $70 \mathrm{Lh}^{-1}$. In a poor flame, it can form a refractory $\mathrm{Zn}$ oxide, because above $70 \mathrm{Lh}^{-1}$, the analytical signal was increased. Therefore, the fuel flow for the three elements was $70 \mathrm{Lh}^{-1}$, taking into consideration the profile and standard deviation of the absorbance signal. After the optimization of the fuel flow, the observation height was studied (see Figure 1). The best height was chosen considering the profile and standard deviation of the absorbance signal; $8 \mathrm{~mm}$ was applied in the $\mathrm{Cu}, \mathrm{Fe}$, and $\mathrm{Zn}$ determination in the samples. The evaluation of this parameter is important, because high absorbance signal represents the interaction of the radiation from the hollow cathode lamp with gaseous atoms in the fundamental state.

3.2. Figures of Merit. Characteristic parameters of the analytical calibration curve, such as linear range, correlation coefficient $\left(R^{2}\right)$, average RSD for repeatability of calibration solution measurements $(n=5)$, and LOD and LOQ (in $\mu \mathrm{g} \mathrm{g}^{-1}$ ) are presented in Table 2. The quality of the results obtained with F AAS and ICP OES was checked by analysing SRM 1515 and SRM 1572, respectively, which were submitted to the same experimental procedures adopted for the samples. The comparison between experimental and certified values for all analytes is presented in Table 3 . The results showed that the methods were selective and accurate, and they are in good agreement with Student's $t$-test at a 95\% confidence limit.

Analytical solutions of $\mathrm{Cu}, \mathrm{Fe}$, and $\mathrm{Zn}$ were added to a sample mass (raw and cooked beans) before acid digestion in the microwave oven. The influence of concomitants in $\mathrm{Cu}, \mathrm{Fe}$, and $\mathrm{Zn}$ determinations with F AAS and analyte losses during the sample preparation (digestion) were investigated through an addition and recovery test (see Table 3 ). The recoveries (see Table 3) showed an absence of chemical interference in the elemental determination and no losses or contamination in the sample pretreatment step. According to NBR ISO/IEC 17025 [18], the recovery tolerance ranged from $70 \%$ to $120 \%$.

\subsection{Cooking Effects on Essential Element Concentrations in} Beans. The elemental concentrations of cooked and raw Phaseolus species are shown in Table 4. Between the species, these concentrations were different, due to genetic, environmental, and processing factors. However, the influence of growing location, seasonal variation, cultivation practices, and between-plant variation can be determined only through an analysis of chemical composition [8]. In raw Brazilian beans, $\mathrm{Ca}, \mathrm{Cu}, \mathrm{K}$, and $\mathrm{Mg}$ were present mainly in the rajado species, $\mathrm{Cu}$ in jalo, Fe in black, $\mathrm{S}$ and $\mathrm{Zn}$ in fradinho, and $\mathrm{P}$ in rosinha. After cooking, the highest $\mathrm{Cu}, \mathrm{Fe}$, and $\mathrm{Zn}$ 
TABLE 2: Parameters of the analytical calibration curves: linear range, correlation coefficient $\left(R^{2}\right)$, average (RSD) for repeatability of calibration solutions measurements, and limits of detection (LOD) and quantification (LOQ) for the studied elements.

\begin{tabular}{lccccc}
\hline Element & $\begin{array}{c}\text { Linear range } \\
(\mathrm{mg} / \mathrm{L})\end{array}$ & $R^{2}$ & $\begin{array}{c}\text { RSD } \\
(\%)\end{array}$ & $\begin{array}{c}\text { LOD } \\
\left(\mu \mathrm{gg}^{-1}\right)\end{array}$ & $\begin{array}{c}\mathrm{LOQ} \\
\left(\mu \mathrm{gg}^{-1}\right)\end{array}$ \\
\hline $\mathrm{Cu}$ & $0.10-4.0$ & 0.9908 & 5.2 & 1.4 & 4.6 \\
$\mathrm{Fe}$ & $0.25-3.0$ & 0.9954 & 5.4 & 1.9 & 6.2 \\
$\mathrm{Zn}$ & $0.15-0.80$ & 0.9846 & 6.3 & 2.7 & 9.1 \\
\hline \multicolumn{5}{c}{ ICP OES } \\
$\mathrm{Ca}$ & $10-200$ & 0.9910 & 1.0 & 1.5 & 5.0 \\
$\mathrm{~K}$ & $10-200$ & 0.9995 & 1.4 & 6.7 & 22 \\
$\mathrm{Mg}$ & $10-200$ & 0.9931 & 1.5 & 1.1 & 3.6 \\
$\mathrm{P}$ & $10-200$ & 0.9983 & 2.4 & 1.9 & 6.2 \\
$\mathrm{~S}$ & $10-200$ & 0.9981 & 2.3 & 0.94 & 3.1 \\
\hline
\end{tabular}

TABLE 3: Recovery values and concentrations of $\mathrm{Cu}, \mathrm{Fe}$, and $\mathrm{Zn}$ in the certified reference material (SRM 1515-apple leaves).

(a) F AAS

\begin{tabular}{lcccc}
\hline \multirow{2}{*}{ Element } & \multicolumn{2}{c}{ Recovery test $(\%)$} & \multicolumn{2}{c}{$\begin{array}{c}\text { Concentration }\left(\mu \mathrm{gg}^{-1}\right) \\
\pm \text { standard deviation }(n=3)\end{array}$} \\
\cline { 2 - 5 } & Raw & Cooked & Certified value & Found value \\
\hline $\mathrm{Cu}$ & 112 & 81 & $5.46 \pm 0.24$ & $5.47 \pm 0.27$ \\
$\mathrm{Fe}$ & 84 & 108 & $83 \pm 5$ & $79 \pm 1$ \\
$\mathrm{Zn}$ & 90 & 94 & $12.5 \pm 0.3$ & $12.5 \pm 2.3$ \\
\hline
\end{tabular}

(b) ICP OES

\begin{tabular}{lcc}
\hline Element & $\begin{array}{c}\text { Concentration }\left(\mu \mathrm{g} \mathrm{g}^{-1}\right) \pm \text { standard deviation }(n=3) \\
\text { Certified value }\end{array}$ & $\begin{array}{c}\text { Found value } \\
\mathrm{Ca}\end{array}$ \\
$\mathrm{K}$ & $3.15 \pm 0.10^{\mathrm{a}}$ & $3.13 \pm 0.88^{\mathrm{a}}$ \\
$\mathrm{Mg}$ & $0.82 \pm 0.06^{\mathrm{a}} \pm 0.03^{\mathrm{a}}$ & $1.64 \pm 0.36^{\mathrm{a}}$ \\
$\mathrm{P}$ & $0.13 \pm 0.02^{\mathrm{a}}$ & $0.53 \pm 0.12^{\mathrm{a}}$ \\
$\mathrm{S}$ & $0.407 \pm 0.009$ & $0.11 \pm 0.03^{\mathrm{a}}$ \\
\hline
\end{tabular}

${ }^{a_{\%} w / w}$.

concentrations were found in the same raw species. However, $\mathrm{Ca}, \mathrm{Mg}$, and $\mathrm{S}$ were present in the black species, whereas $\mathrm{K}$ and $\mathrm{P}$ were present in the jalo species.

Studies of the chemical composition of food are critical from the nutritional and toxicological points of view. The amount of an essential nutrient considered adequate for human requirements is called the dietary reference intake. US Food and Drug Administration regulations require nutrition labelling for most foods. Reference daily intakes for some essential elements of human nutrition and daily reference values have been established, namely: $\mathrm{Ca}(1000 \mathrm{mg}), \mathrm{Cl}$ (3400 mg), Cu (2 mg), Fe (18 mg), K (3500 mg), Mg (400 mg), Mn (2 mg), P (1000 mg), and Zn (15 mg) [19]. Considering the concentrations of these elements (see Table 4) and the consumed amount (approximately $170 \mathrm{~g}$ ) of the different species of the cooked beans, the masses of these ingested elements ranged from 107 (fradinho) to 281 (black) $\mathrm{mg}$ for Ca, 10 (fradinho) to 17 (jalo) $\mathrm{mg}$ for $\mathrm{Fe}, 0.6$ (bolinha) to 2.4 (black) for $\mathrm{Cu}, 1423$ (fradinho) to 2125 (jalo) $\mathrm{mg}$ for K, 114 (bolinha) to 167 (black) $\mathrm{mg}$ for $\mathrm{Mg}, 583$ (rosinha) to 889 (jalo) $\mathrm{mg}$ for $\mathrm{P}$, 275 (rosinha) to 386 (preto) $\mathrm{mg}$ for S, and 6 (rajado and black) to 9 (fradinho) for $\mathrm{Zn}$. Daily reference values can be achieved depending on the bean species and consumed amount.

The thermal treatment applied to beans improves protein and starch digestibility and raises nutritive value by reducing antinutrients such as phytic acid and tannins [2]. However, information regarding the effect of thermal treatment on essential element concentrations in beans remains limited. Comparing the results of the raw and cooked beans (see Table 4) and applying Student's $t$-test at a 95\% confidence limit, the $\mathrm{Cu}, \mathrm{Fe}, \mathrm{S}$, and $\mathrm{Zn}$ concentrations were unaltered by cooking. In jalo and black species, the heating increased $\mathrm{Ca}, \mathrm{K}, \mathrm{Mg}, \mathrm{P}$, and $\mathrm{Zn}$ concentrations. Contamination may have occurred during acid digestion, cooking, or both. Contaminations of the deionized water used in the cooking were discarded, due to production of analytical blank. Additionally, cooking decreased Ca concentration in the fradinho and rajado species and Fe concentration in the jalo and rajado species. Reduction in essential element concentrations may be the result of the discarding of the soaking water. Studies have shown that soaking beans in water and discarding the water may eliminate a percentage of tannins, phytates, and oligosaccharides [4].

The effects of cooking on soluble iron distribution have been evaluated in legumes, beans, chickpeas, and lentils [12]. Cooking reportedly increases soluble iron content in the cooking water. Additionally, thermal treatment can promote the interaction of accessible species with other components of the human diet, altering bioavailability. An increase in nonheme iron absorption is observed in the presence of ascorbic acid and amino acids, and decreased absorption occurs during interactions with antinutrients such as phytates, polyphenols, and calcium, which are part of the food and, having a varied nature, exert toxic or antinutritional action when ingested in the native form (uncooked or insufficiently cooked foods) [1]. In white beans, traditional cooking has a positive effect on the bioavailability of $\mathrm{Ca}, \mathrm{Zn}$, and Fe. Studies have shown that the digestibility and, hence, absorption of Fe can be improved by heat processing owing to break of protein-iron bonds [7]. Notably, the total concentrations of these essential elements were not modified by cooking, but chemical speciation and bioavailability studies must be undertaken to draw conclusions about thermal effects on chemical species. These studies are important for improving mineral content in cultivated bean species through breeding programs [6].

\section{Conclusion}

Essential element determination with F AAS and ICP OES after acid digestion in a closed microwave oven using diluted oxidant mixture was carried out to evaluate the effect of cooking on various Phaseolus species. The total concentrations of essential elements in raw beans of seven Phaseolus species 
TABLE 4: Mineral characterization of beans and the effect of domestic cooking.

\begin{tabular}{|c|c|c|c|c|c|c|c|c|}
\hline \multirow{2}{*}{ Species } & \multicolumn{8}{|c|}{ Concentration \pm standard deviation $^{c}$} \\
\hline & $\mathrm{Ca}^{\mathrm{a}}$ & $\mathrm{Cu}^{\mathrm{b}}$ & $\mathrm{Fe}^{\mathrm{b}}$ & $\mathrm{K}^{\mathrm{a}}$ & $\mathrm{Mg}^{\mathrm{a}}$ & $\mathrm{P}^{\mathrm{a}}$ & $S^{a}$ & $\mathrm{Zn}^{\mathrm{b}}$ \\
\hline \multicolumn{9}{|l|}{ Jalo } \\
\hline Raw & $0.93 \pm 0.12$ & $14 \pm 2$ & $84 \pm 2$ & $8.9 \pm 0.3$ & $0.61 \pm 0.07$ & $3.4 \pm 0.1$ & $1.8 \pm 0.1$ & $35 \pm 3$ \\
\hline Cooked & $0.96 \pm 0.15$ & $14 \pm 1$ & $79 \pm 2$ & $13 \pm 1$ & $0.96 \pm 0.11$ & $5.2 \pm 0.1$ & $2.1 \pm 0.1$ & $48 \pm 3$ \\
\hline \multicolumn{9}{|l|}{ Fradinho } \\
\hline Raw & $0.84 \pm 0.16$ & $3.1 \pm 1.8$ & $61 \pm 5$ & $8.1 \pm 0.4$ & $0.57 \pm 0.09$ & $3.5 \pm 0.1$ & $2.0 \pm 0.1$ & $58 \pm 4$ \\
\hline Cooked & $0.63 \pm 0.15$ & $3.4 \pm 0.2$ & $64 \pm 1$ & $8.4 \pm 0.4$ & $0.97 \pm 0.12$ & $4.4 \pm 0.1$ & $2.1 \pm 0.1$ & $52 \pm 3$ \\
\hline \multicolumn{9}{|l|}{ Rajado } \\
\hline Raw & $0.96 \pm 0.17$ & $14 \pm 3$ & $75 \pm 9$ & $9.7 \pm 0.5$ & $0.70 \pm 0.13$ & $3.4 \pm 0.1$ & $1.7 \pm 0.1$ & $35 \pm 5$ \\
\hline Cooked & $0.77 \pm 0.14$ & $11 \pm 1$ & $68 \pm 3$ & $11 \pm 1$ & $0.88 \pm 0.10$ & $3.9 \pm 0.1$ & $1.7 \pm 0.1$ & $35 \pm 3$ \\
\hline \multicolumn{9}{|l|}{ Bolinha } \\
\hline Raw & $0.72 \pm 0.15$ & $9.7 \pm 2.9$ & $61 \pm 4$ & $7.4 \pm 0.3$ & $0.53 \pm 0.10$ & $3.1 \pm 0.1$ & $1.7 \pm 0.1$ & $36 \pm 4$ \\
\hline Cooked & $0.77 \pm 0.15$ & $8.4 \pm 0.2$ & $59 \pm 1$ & $9.5 \pm 0.4$ & $0.67 \pm 0.09$ & $3.5 \pm 0.1$ & $1.7 \pm 0.1$ & $38 \pm 4$ \\
\hline \multicolumn{9}{|l|}{ Rosinha } \\
\hline Raw & $0.61 \pm 0.13$ & $13 \pm 5$ & $56 \pm 3$ & $8.1 \pm 0.4$ & $0.67 \pm 0.09$ & $3.7 \pm 0.1$ & $1.9 \pm 0.1$ & $35 \pm 4$ \\
\hline Cooked & $0.99 \pm 0.17$ & $10 \pm 1$ & $60 \pm 1$ & $9.1 \pm 0.4$ & $0.71 \pm 0.10$ & $3.4 \pm 0.1$ & $1.6 \pm 0.1$ & $38 \pm 4$ \\
\hline \multicolumn{9}{|l|}{ Black } \\
\hline Raw & $0.76 \pm 0.19$ & $12 \pm 6$ & $94 \pm 3$ & $8.8 \pm 0.5$ & $0.60 \pm 0.12$ & $3.6 \pm 0.1$ & $1.8 \pm 0.1$ & $33 \pm 4$ \\
\hline Cooked & $2.2 \pm 0.3$ & $11 \pm 1$ & $101 \pm 2$ & $11 \pm 1$ & $0.98 \pm 0.12$ & $4.4 \pm 0.1$ & $2.3 \pm 0.1$ & $35 \pm 3$ \\
\hline \multicolumn{9}{|l|}{ Common } \\
\hline Raw & $0.86 \pm 0.20$ & $9.6 \pm 2.6$ & $87 \pm 9$ & $7.5 \pm 0.5$ & $0.55 \pm 0.15$ & $3.3 \pm 0.1$ & $1.7 \pm 0.1$ & $33 \pm 8$ \\
\hline Cooked & $1.6 \pm 0.3$ & $9.8 \pm 1.2$ & $81 \pm 2$ & $11 \pm 1$ & $0.82 \pm 0.13$ & $4.1 \pm 0.1$ & $1.0 \pm 0.1$ & $36 \pm 4$ \\
\hline
\end{tabular}

${ }^{\mathrm{a}}$ Concentration in $\mathrm{mg} \mathrm{g}^{-1}$.

${ }^{\mathrm{b}}$ Concentration in $\mu \mathrm{g} \mathrm{g}^{-1}$.

${ }^{c} n=3$.

displayed the potentialities of each species related to these elements. The differences are related to plant physiology, growing location, and environmental conditions. Concentrations of $\mathrm{Cu}, \mathrm{Fe}, \mathrm{S}$, and $\mathrm{Zn}$ were unaltered by cooking. Increases in $\mathrm{Ca}, \mathrm{K}, \mathrm{Mg}, \mathrm{P}$, and $\mathrm{Zn}$ concentrations were observed for jalo and black species. Conversely, a decrease in $\mathrm{Ca}$ concentration in the fradinho and rajado species and in Fe concentration in the jalo and rajado species was observed.

\section{Conflict of Interests}

The authors declare that there is no conflict of interests regarding the publication of this paper.

\section{Acknowledgments}

The authors are grateful to professors Pedro Vitoriano de Oliveira and Cassiana Seimi Nomura, both of the Chemistry Institute of the Sao Paulo University, for laboratory infrastructure support. Juliana Naozuka thanks the Fundação de Amparo à Pesquisa do Estado de São Paulo (2012/11517-1) for financial support. Gislayne A. R. Kelmer has received scholarship from Fundação de Amparo à Pesquisa do Estado de São Paulo (2012/00133-8).

\section{References}

[1] P. Brigide and S. G. Canniatti-Brazaca, "Antinutrients and "in vitro" availability of iron in irradiated common beans
(Phaseolus vulgaris)," Food Chemistry, vol. 98, no. 1, pp. 85-89, 2006.

[2] L. G. Ranilla, M. I. Genovese, and F. M. Lajolo, "Effect of different cooking conditions on phenolic compounds and antioxidant capacity of some selected Brazilian bean (Phaseolus vulgaris L.) cultivars," Journal of Agricultural and Food Chemistry, vol. 57, no. 13, pp. 5734-5742, 2009.

[3] J. Naozuka and P. V. Oliveirab, "Cooking effects on iron and proteins content of beans (Phaseolus vulgaris L.) by GF AAS and MALDI-TOF MS," Journal of the Brazilian Chemical Society, vol. 23, no. 1, pp. 156-162, 2012.

[4] A. C. Fernandes, W. Nishida, and R. P. da Costa Proença, "Influence of soaking on the nutritional quality of common beans (Phaseolus vulgaris L.) cooked with or without the soaking water: a review," International Journal of Food Science \& Technology, vol. 45, no. 11, pp. 2209-2218, 2010.

[5] J. Słupski, "Effect of cooking and sterilisation on the composition of amino acids in immature seeds of flageolet bean (Phaseolus vulgaris L.) cultivars," Food Chemistry, vol. 121, no. 4, pp. 1171-1176, 2010.

[6] S. Saha, G. Singh, V. Mahajan, and H. S. Gupta, "Variability of nutritional and cooking quality in bean (Phaseolus vulgaris $\mathrm{L}$ ) as a function of genotype," Plant Foods for Human Nutrition, vol. 64, no. 2, pp. 174-180, 2009.

[7] N. Wang, D. W. Hatcher, R. T. Tyler, R. Toews, and E. J. Gawalko, "Effect of cooking on the composition of beans (Phaseolus vulgaris L.) and chickpeas (Cicer arietinum L.)," Food Research International, vol. 43, no. 2, pp. 589-594, 2010.

[8] J. M. Harnly, M. A. Pastor-Corrales, and D. L. Luthria, "Variance in the chemical composition of dry beans determined from 
UV spectral fingerprints," Journal of Agricultural and Food Chemistry, vol. 57, no. 19, pp. 8705-8710, 2009.

[9] R. Bressani, "Grain quality of common beans," Food Reviews International, vol. 9, no. 2, pp. 237-297, 1993.

[10] M. Candela, I. Astiasaran, and J. Bello, "Cooking and warm-holding: effect on general composition and amino acids of kidney beans (Phaseolus vulgaris), chickpeas (Cicer arietinum), and lentils (Lens culinaris)," Journal of Agricultural and Food Chemistry, vol. 45, no. 12, pp. 4763-4767, 1997.

[11] C. R. Meiners, N. L. Derise, H. C. Lau, M. G. Crews, S. J. Ritchey, and E. W. Murphy, "The content of nine mineral elements in raw and cooked mature dry legumes," Journal of Agricultural and Food Chemistry, vol. 24, no. 6, pp. 1126-1130, 1976.

[12] V. M. O. Carioni, R. Chelegão, J. Naozuka, and C. S. Nomura, "Feasibility study for the preparation of a tuna fish candidate reference material for total As determination," Accreditation and Quality Assurance, vol. 16, no. 8, pp. 453-458, 2011.

[13] J. Naozuka and C. S. Nomura, "Total determination and direct chemical speciation of $\mathrm{Hg}$ in fish by solid sampling GF AAS," Journal of Analytical Atomic Spectrometry, vol. 26, no. 11, pp. 2257-2262, 2011.

[14] A. Quinteros, R. Farré, and M. J. Lagarda, “Optimization of iron speciation (soluble, ferrous and ferric) in beans, chickpeas and lentils," Food Chemistry, vol. 75, no. 3, pp. 365-370, 2001.

[15] J. Naozuka, E. Carvalho Vieira, A. N. Nascimento, and P. V. Oliveira, "Elemental analysis of nuts and seeds by axially viewed ICP OES," Food Chemistry, vol. 124, no. 4, pp. 1667-1672, 2011.

[16] IUPAC, "Nomenclature, symbols, units and their usage in spectrochemical analysis-II. Data interpretation analytical chemistry division," Spectrochimica Acta, vol. 33, no. 6, pp. 241245, 1978.

[17] D. J. Halls, "The role of various flame constituents in the production of atoms in the air-acetylene flame," Analytica Chimica Acta, vol. 88, no. 1, pp. 69-77, 1977.

[18] R. Burin, V. M. Burin, P. Taha, and M. T. Bordignon-Luiz, "Validação de uma metodologia analítica para determinação de cálcio em produtos cárneos," Ciência e Tecnologia de Alimentos, vol. 28, no. 4, pp. 973-978, 2008.

[19] S. P. Dolan and S. G. Capar, "Multi-element analysis of food by microwave digestion and inductively coupled plasma-atomic emission spectrometry," Journal of Food Composition and Analysis, vol. 15, no. 5, pp. 593-615, 2002. 

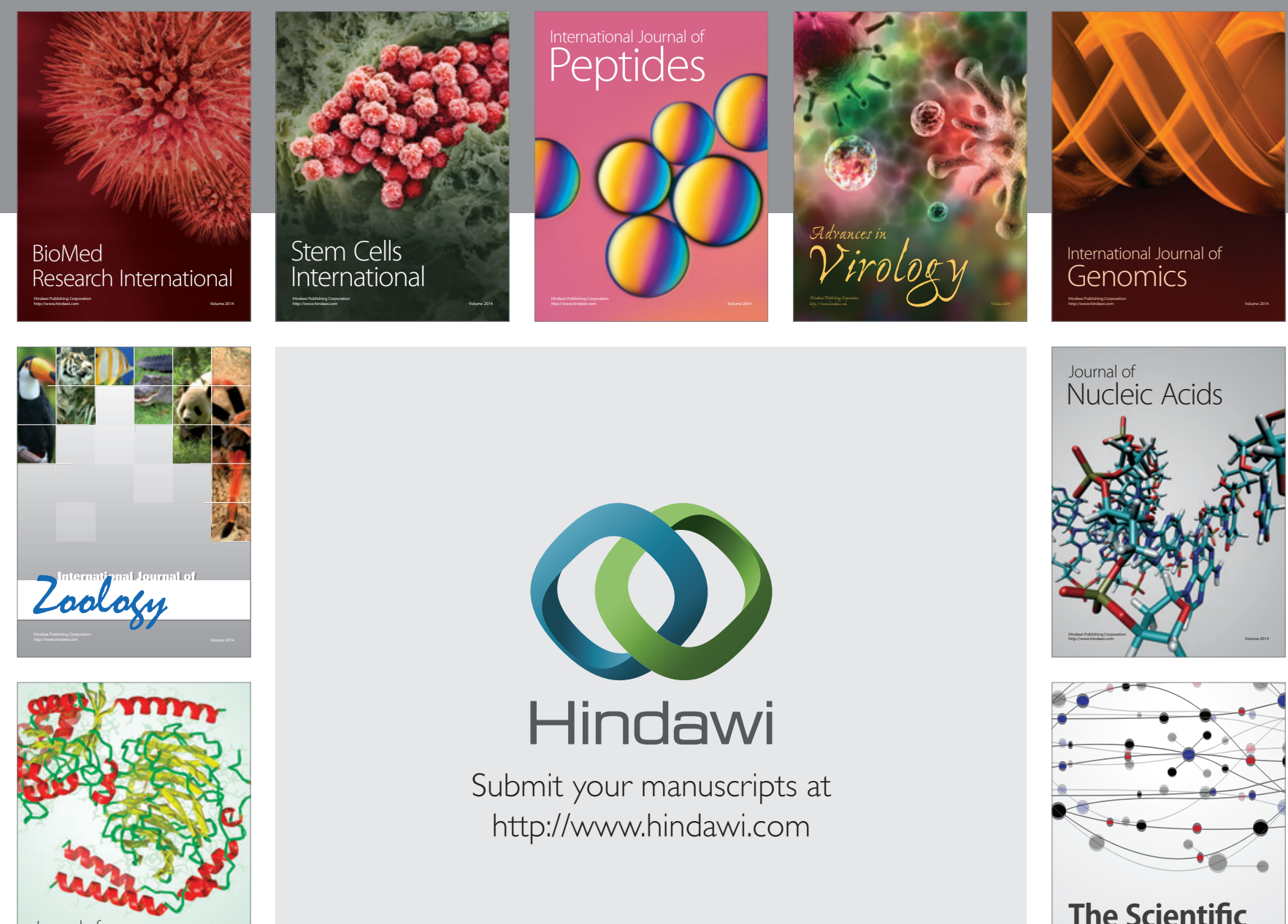

Submit your manuscripts at

http://www.hindawi.com

Journal of
Signal Transduction
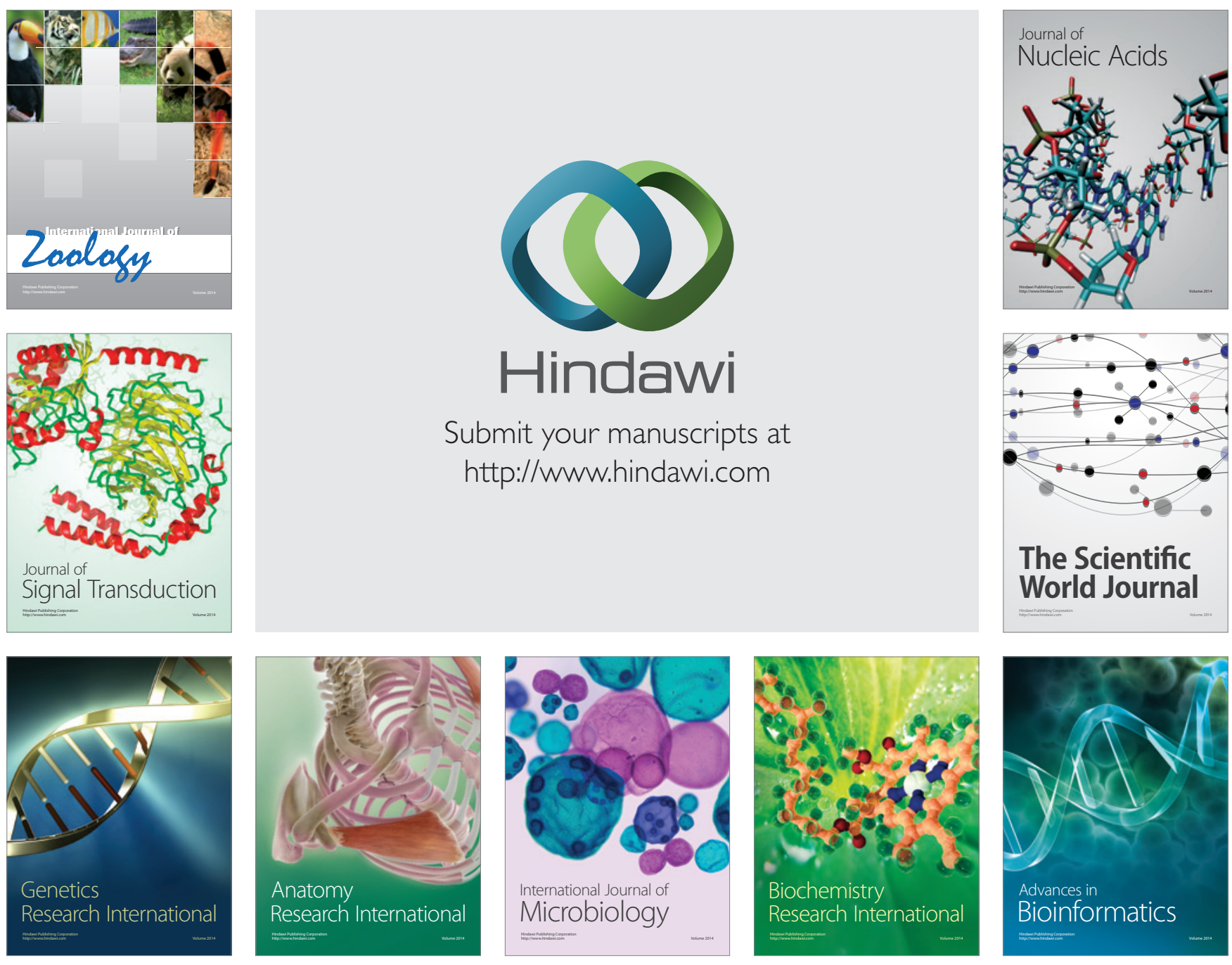

The Scientific World Journal
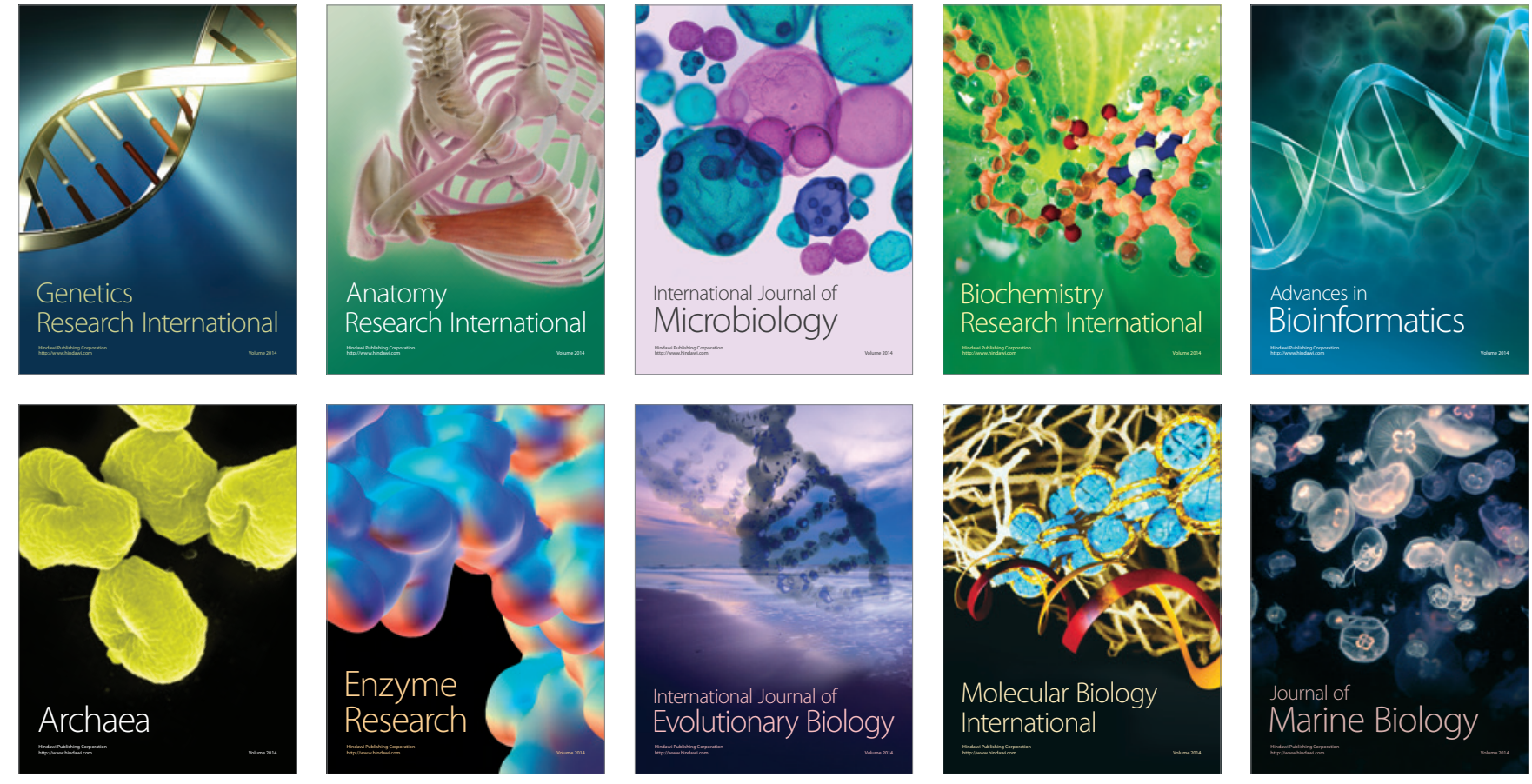